Бочкарева Юлия Валерьевна, канд. с.-х. наук, доцент кафедры «Частное право и экологическая безопасность», Саратовский социально-экономический институт (филиал) РЭУ им. Г.В. Плеханова. Россия.

410031, г. Саратов, ул. Московская, 37.

Тел.: (8452) 23-69-71.

Егунова Алла Владимировна, канд. биол. наук, доиент кафедры «Болезни животных и ветеринарно-санитарная экспертиза», Саратовский государственный аграрный университет имени Н.И. Вавилова. Россия.
Копчекчи Марина Егоровна, канд. вет. наук, доцент кафедры «Морфология, патология животных и биология», Саратовский государственный аграрный университет имени Н.И. Вавилова. Россия.

410005, г. Саратов, ул. Соколовая, 335.

Тел.: (8452) 69-25-32.

Ключевые слова: фиктивная нормодонтия; полиодонтия; одонтопатология; окклюзионные щзели; дентиция зубов.

\title{
MAJOR ANATOMICAL AND MORPHOLOGICAL SIGNS OF DIFFERENCE OF TWO GENERATIONS TEETH IN DOGS
}

Phrolov Valeriy Vladimirovich, Doctor of Biological Sciences, Professor of the chair "Private Law and Environmental Safety”, Saratov Socio-Economic Institute (branch) Russian Economic University named after G.V. Plekhanov. Russia.

Bochkareva Yulia Valeryevna, Candidate of Agricultural Sciences, Associate Pro-fessor of the chair "Private Law and Environmental Safety", Saratov Socio-Economic Institute (branch) Russian Economic University named after G.V. Plekhanov. Russia.

Egunova Alla Vladimirovna, Candidate of Biological Sciences, Associate Professor of the chair "Animals' Diseases and Veterinarian-Sanitarian Expertise", Saratov State Agrarian University named after N.I. Vavilov. Russia.
Kopchekchi Marina Egorovna, Candidate of Veterinary Sciences, Associate Professor of the chair "Morphology, Pathology of Animals and Biology", Saratov State Agrarian University named after N.I. Vavilov. Russia.

Keywords: fictitious normodontia; polyodontia; odontopathology; occlusal embrasure; dentition of teeth.

The morphological features of milk and secondary teeth are shown. The revealed features of the structure of these teeth represent not only a picture of their own differences, but also allow us to observe the development of dentition, to correct them, as well as to provide clinical monitoring of the dental apparatus.

\section{МЕТАГЕНОМНЫЙ АНАЛИЗ ДЛЯ МУЛЬТИПРАЙМЕРНОЙ ПЦР-ИНДИКАЦИИ ВИРУСОВ МЕДОНОСНОЙ ПЧЕЛЫ}

\begin{abstract}
ХАММАДОВА Альфия Василевна, Казанский (Приволжский) федеральный университет МУкМинов Малик Нилович, Казанский (Приволжский) федеральный университет ШУРАЛЕВ Эдуард Аркадьевич, Казанский (Приволжский) федеральный университет ХАММАДОВ Наиль Ильдарович, Федеральный центр токсикологической, радиационной и биологической безопасности
\end{abstract}

\section{ФАИЗОВ Тагир Хадиевич, Федеральный центр токсикологической, радиационной} и биологической безопасности

Рассмотрено конструирование праймеров для индикации и идентификации возбудителей вирусных заболеваний пчел (мешотчатого расплода, острого паралича, черного маточника, деформации крыла) методом мультипраймерной ПЦР. На основе биоинформационного анализа произведен дизайн олигонуклеотидных затравок. Сконструированные праймеры имели схожие температуры отжига $\left(60^{\circ} \mathrm{C}\right)$, ито позволяет проводить индикацию каждого из вирусов при единых условиях ПЦР. С данным комплексом олигонуклеотидных затравок амплифицируется больиинство известных итаммов и изолятов указанных вирусов. Нуклеотидные последовательности праймеров и универсального положительного контроля позволяют проводить генетическую идентификацию каждого из представленных биопатогенов в одних и техже условиях ПЦР в мультипраймерном формате.

Введение. К болезням медоносной пчелы (Apis mellifera L.), сдерживающим развитие пчеловодства, относятся варроатоз и сопряженные с ним инфекции (микозы и вирозы) и инвазии (акарапидоз, браулез, амебиаз), приводящие к снижению продуктивности пораженных семей, а зачастую и гибели [8]. Наиболее актуальными патогенами, поражающими пчел, являются вирус мешотчатого расплода (Sacbrood virus, $\mathrm{SBV}$ ), вирус острого паралича (Acute bee paralysis virus, ABPV), вирус черного маточника (Black queen cell virus, BQCV), вирус деформации крыла (Deformed wing virus, DWV) и др. [10].
Опасность вирусов обусловлена их длительным существованием в организме хозяина без клинической симптоматики, быстрым распространением, как в пчелиной семье, так и вне ее, наличием эктопаразитов-переносчиков и способностью при определенных условиях нанести значительный экономический ущерб пчеловодству. На интенсивность распространения вирусных заболеваний могут оказывать влияние эколого-географические условия $[6,7,9]$, загрязненность окружающей среды поллютантами [12], наличие клещей - переносчиков возбудителей инфекционных заболеваний пчел [11]. 
Методом ОТ-ПЦР в регионах России установлено широкое распространение РНК-содержащих вирусов пчел, в том числе и проявление смешанных инфекций, чему также способствует высокое инфицирование клеща Varroa destructor [3, 4]. Вирусы очень быстро распространяются по территории и покрывают обширные области, с чем связано распространение европейских вирусов в азиатских странах [16], что, возможно, также связано и с пораженностью диких пчел [15]. Усиленное размножение вирусов повышает их вирулентность, что приводит к росту смертности среди насекомых, а в некоторых случаях и к краху всей пчелиной семьи.

Для эффективной борьбы с вирусными заболеваниями пчел необходима своевременная и точная диагностика. Главным способом диагностики вирусных инфекций стали лабораторные исследования [5]. Максимальной специфичностью среди различных диагностических методов обладает генодиагностика вирусных заболеваний [2]. Имеются данные о разработке ПЦР-диагностики вирозов пчел, однако каждый набор праймеров в диагностике требует своих условий постановки реакции, в первую очередь температурных. Полногеномные исследования вирусов указывают на присутствие определенных различий внутри одного вида и даже внутри отдельной популяции [14]. Для диагностики каждого из интересующих нас вирусных заболеваний необходимы анализ геномов различных типов и изолятов вирусов, как и других биопатогенов [1], определение максимально гомогенных участков и проверка вероятности возможных перекрестных реакций.

Цель данной работы - конструирование праймеров для индикации и идентификации возбудителей вирусных заболеваний пчел методом мультипраймерной ПЦР.

Методика исследований. При дизайне праймеров и зондов пользовались ресурсами National Center for Biotechnology Information (NCBI), Basic Local Alignment Search Tool (BLAST) (https://blast.ncbi.nlm. nih.gov/Blast.cgi) и программой VectorNTI 9.1.0. (Invitrogen Corporation). При этом соблюдали следующее: минимальное количество димеров и вторичных структур, одинаковая температура отжига праймеров $\left( \pm 0,5^{\circ} \mathrm{C}\right)$, минимум гуанинов и цитазинов на 3 , конце каждого из праймеров; для положительного контроля необходима только абсолютная комплементарность к праймерам и зонам с нужной последовательностью, с возможностью синтеза ПЦР-продукта длиной около 100 пар нуклеотидов, зонд для ПЦР не должен содержать гуанин на 5' конце.

С целью применения в мультипраймерной ПЦР ставилась задача сконструировать уникальный положительный контроль, содержащий комплиментарную нуклеотидную последовательность ко всем олигонуклиотидным затравкам искомых вирусов.

При работе с подмором пчел проводили пробоподготовку, включающую в себя такие этапы, как измельчение, гомогенезацию и экстракцию. Выделение нуклеиновых кислот проводили методом магнитной сорбции с комплектом реагентов «МАГНО-сорб» вариант 100-200 («АмплиСенс»
ФБУН ЦНИИ эпидемиологии Роспотребнадзора) согласно инструкции производителя.

Для ПЦР амплификации использовали следующий состав реакционной смеси, из расчета на одну пробу: 1,5 мкл $25 \mathrm{mM}$ раствора $\mathrm{MgCl}_{2} ; 1,5$ мкл $2.5 \mathrm{mM}$ раствора dNTP; 1,5 мкл 10x буфера для ПЦР; 0,5 мкл 10 рМ раствора зонда для ПЦР; $10 \mathrm{pM}$ раствора прямого и обратного праймеров по 0,5 мкл; 0,5 мкл Таq-полимеразы; 5 мкл ДНК и 3,5 деионизированной воды. Для ПЦР использовали реактивы производства $3 А О$ «Синтол» (г. Москва). Конечный объем реакционной смеси составил 15 мкл. Реакционная смесь для ОТ-ПЦР (ПЦР с обратной транскрипцией молекулы РНК) отличалась от вышеуказанной смеси наличием фермента MMLV для обратной транскрипции (ЗАО «Евроген», г. Москва), 0,2 мкл на одну реакцию.

ПЦР-РВ (ПЦР в режиме реального времени) осуществляли на амплификаторе С1000 с оптическим блоком CFX96 (BioRad). Программа для амплификации: (I) денатурация ДНК при $95^{\circ} \mathrm{C}$ в течение 2 мин; (II) 40 циклов, состоящих из 10 с при $95{ }^{\circ} \mathrm{C}, 30$ с при $60{ }^{\circ} \mathrm{C}$. Детекция результата ПЦР (флуоресценции) происходит на каждом из 40 циклов второй стадии ПЦР, при $60^{\circ} \mathrm{C}$ по каналу FAM. ОТ-ПЦР осуществляли по схожей программе с добавлением этапа обратной транскрипции $\left(37^{\circ} \mathrm{C}\right.$ в течение 30 мин) до основной программы амплификации.

Вставку нуклеотидной последовательности положительного контрольного образца в плазмидный вектор заказывали в ЗАО «Евроген». Концентрацию препарата плазмидной ДНК со вставкой определяли на спектрофотометре UV5 (Mettler Toledo) согласно инструкции к прибору.

Результаты исследований. Определение маркерных последовательностей для геноиндикации вирусов. Геном вирусов SBV, ABPV, BQCV и DWV представлен РНК длиной от 8,5 до 10,2 тыс. bp (табл. 1), что позволяет производить поиск маркерных последовательностей, пригодных для индикации данных вирозов, анализируя полногеномную нуклеотидную последовательность.

При выравнивании нуклеотидной последовательности различных штаммов и изолятов каждого вируса биоинформационным анализом определены наиболее гомологичные локусы, которые можно использовать в качестве маркерной последовательности для индикации анализируемых вирусов пчел (табл. 2).

Маркерная последовательность вирусов SBV, ABPV и BQCV обнаружена лишь в геноме вирусов, на индикацию которых направлена нуклеотидная последовательность маркерной области. Маркерная же последовательность вируса DWV также присутствует в геноме таких организмов, как Kakugo virus и Varroa destructor virus, при этом первый является подтипом вируса DWV [12], а второй - проявлением DWV в организме клеща варроа, паразитирующего на пчелах.

Исходя из вариабельности нуклеотидной последовательности различных штаммов и изолятов каждого из вирусов, были определены нуклеотид- 
ные последовательности праймеров и зондов для индикации максимально большего их числа методом ПЦР-РВ.

Конструирование праймеров и зондов для ПЦР. В области маркерной последовательности каждого вируса были определены короткие (20-40 bp) нуклеотидные последовательности (прямой (F) и обратный $(\mathrm{R})$ праймеры и зонды (Z)), которые давали возможность определить максимальное количество изолятов и штаммов вирусов), см. обложку, рис. 1. Сконструированные нуклеотидные последовательности праймеров и зондов предполагают выявление штаммов и изолятов каждого из определяемых вирусов в количестве, указанном выше (см. табл. 2). Представленные их характеристики указывают на возможность успешной амплификации при одинаковых режимах, что определяет их использование для геноиндикации целевых вирусов (табл. 3).

При прикреплении к зондам различных флуоресцентных меток (для каждого вируса своя метка) возможна реализация мультиплексного подхода к ПЦР$\mathrm{PB}$, с амплификацией всех четырех вирусов в одной пробирке или раздельной амплификацией в одном термоблоке (нуклеотидная последовательность праймеров и зондов подразумевает амплификацию при одинаковых условиях ПЦР).

Создание положительного контрольного образияа. Положительный контроль должен представлять молекулу плазмидной ДНК, в нуклеотидной последовательности которой встречаются маркерные последовательности для индикации всех определяемых вирусов, наличие данных вставок не должно нарушать функциональность имеющихся в плазмиде генов. Для реализации возможности создания положительного контроля сразу на 4 вируса, не сильно увеличивая при этом длину вставки (когда применяется вся маркерная последовательность линейно), мы интегрировали нуклеотидные после- довательности для индикации вирусов пчел друг в друга (чередование праймеров и зондов к разным вирусам). Схематично данная вставка выглядит так: «5` $\operatorname{SBV}(\mathrm{F}), \operatorname{ABPV}(\mathrm{F}), \operatorname{SBV}(\mathrm{Z}), \operatorname{ABPV}(\mathrm{Z}), \operatorname{SBV}(\mathrm{R})$, $\mathrm{ABPV}(\mathrm{R}), \mathrm{BQCV}(\mathrm{F}), \mathrm{DWV}(\mathrm{F}), \mathrm{BQCV}(\mathrm{Z}), \mathrm{DWV}(\mathrm{Z})$, $\mathrm{BQCV}(\mathrm{R}), \mathrm{DWV}(\mathrm{R}) 3^{`} \gg$. Полученную нуклеотидную последовательность положительного контроля вставили в вектор «pFLD», характеристика данной плазмиды представлена в виде карты (см. обложку, рис. 2).

Амплификация сконструированного положительного контроля с праймерами для индикации SBV синтезирует ампликон молекулярной массой $153 \mathrm{bp}$, для ABPV - 159 bp, для BQCV - 149 bр и для DWV 143 bp. Таким образом, в специфичной нуклеотидной последовательности положительного контроля длиной 361 bр имеется возможность амплификации всех определяемых вирусов.

Для подтверждения работоспособности разработанных методов индикации выявляемых вирусов и разработанного положительного контроля производили амплификацию каждого из вирусов в присутствии красителя EvaGreen (см. рисунок).

Таким образом, экспериментальной постановкой ПЦР подтверждена работоспособность специфических праймеров и положительного контроля, сконструированных путем биоинформационного анализа.

Заключение. Произведен дизайн и синтез праймеров вирусов мешотчатого расплода, острого паралича, черного маточника и деформации крыла пчел, нуклеотидная последовательность которых позволяет одновременно анализировать 4 целевых вируса в одном образце с использованием мультипраймерной ПЦР.

Сконструированный комплекс олигонуклеотидных затравок позволяет амплифицировать большинство известных штаммов и изолятов ука-

\section{Краткая характеристика исследуемых вирусов}

\begin{tabular}{|l|c|c|}
\hline \multicolumn{1}{|c|}{ Вирус } & $\begin{array}{c}\text { Величина генома вируса, } \\
\text { bp }\end{array}$ & Ссылка на таксономическую классификацию \\
\hline SBV, штамм AmSBV-Kor1 & 8837 & https://www.ncbi.nlm.nih.gov/Taxonomy/Browser/wwwtax.cgi?id=89463 \\
\hline ABPV, изолят Poland & 9463 & https://www.ncbi.nlm.nih.gov/Taxonomy/Browser/wwwtax.cgi?id=92444 \\
\hline BQCV, штамм PP & 8511 & https://www.ncbi.nlm.nih.gov/Taxonomy/Browser/wwwtax.cgi?id=92395 \\
\hline DWV, изолят 85-DWV & 10149 & https://www.ncbi.nlm.nih.gov/Taxonomy/Browser/wwwtax.cgi?id=198112 \\
\hline
\end{tabular}

Таблица 2

Маркерные локусы анализируемых вирусов пчел

\begin{tabular}{|c|c|c|c|}
\hline Вирус & $\begin{array}{l}\text { Количество выявля- } \\
\text { емых искомых штам- } \\
\text { мов и изолятов }\end{array}$ & $\begin{array}{l}\text { Количество выяв- } \\
\text { ляемых нецелевых } \\
\text { организмов }\end{array}$ & $\begin{array}{c}\text { Маркерная последовательность нуклеиновых кислот } \\
5^{`} \text {-> } 3^{`}\end{array}$ \\
\hline SBV & 97 & 0 & $\begin{array}{c}\text { aatggttgggtttctggtatgtttgttgacaagaacgtccactacaccgaaatgtccagtgatgagagtggacgaag } \\
\text { aatctggaatgttagacgcgcagtgtcaattaagaccgcagaaggaactatagtgtggcgaaaagttattacctcgt } \\
\text { acagttgtaaggtggcttcggaactagctgctaagagtatattggt }\end{array}$ \\
\hline $\mathrm{ABPV}$ & 43 & 0 & $\begin{array}{c}\text { tgatacggagatcaccataagggtaccttttgtttcaaacaaaatgttcatgaaatctacgggaatttatggtggaaat } \\
\text { tctgaaaacaattgggatttctctgaatcatttactggatttttgtgcataagacctatcacaaaattaatgtgtccagag } \\
\text { actgtgtcaaataatgtgtcaatagttgtgtggaagtggg }\end{array}$ \\
\hline $\mathrm{BQCV}$ & 100 & 0 & $\begin{array}{c}\text { aggacggtacggcgttcctcaatgctcgtagtattgaggatagcgatttgttgtgagctcctttagagggagggctca } \\
\text { ctttatctattgcttaaatcggtaagccacaaatttttctaagtgtcatgagtttcttctcggttcttctcatgattactaat } \\
\text { cgaaccgtgtgtagagtcagaatgttgtggttacgttt }\end{array}$ \\
\hline DWV & 45 & 2 & $\begin{array}{c}\text { gaagtgttgaagaaaatgtggggttatgtattttgtcagagtaatcctgcagcgcgtttgttgaaagctgtgaatgac } \\
\text { gagcctgagattttgaaagcatgggtgaaggaatgtctgtatttggatgatcccaaattcagaatgcgtcgagcgcat } \\
\text { gatcaagagtatatcgagagagtgtttgcggcacattcttatgg }\end{array}$ \\
\hline
\end{tabular}


Характеристики сконструированных праймеров и зондов для ПЦР

\begin{tabular}{|c|c|c|c|c|}
\hline Вирус & Вид олигонуклеотида & $\begin{array}{l}\text { Термодинамические } \\
\text { характеристики, }{ }^{\circ} \mathrm{C}\end{array}$ & $\begin{array}{c}\text { Количество / длина } \\
\text { димеров }\end{array}$ & $\begin{array}{l}\text { Количество / длина } \\
\text { вторичных структур }\end{array}$ \\
\hline \multirow{3}{*}{ SBV } & Прямой праймер & 60,0 & $5 / 3$ и 4 & $2 / 3$ \\
\hline & Обратный праймер & 59,9 & $8 / 3$ и 4 & $3 / 3$ \\
\hline & Зонд & 66,0 & $6 / 3$ & $2 / 3$ \\
\hline \multirow{3}{*}{ ABPV } & Прямой праймер & 59,9 & $10 / 3,4$ и 6 & $3 / 3,4$ и 6 \\
\hline & Обратный праймер & 59,8 & $7 / 3$ и 4 & $3 / 3$ \\
\hline & Зонд & 65,0 & $19 / 3,4$ и 6 & $7 / 3$ и 4 \\
\hline \multirow{3}{*}{ BQCV } & Прямой праймер & 60,2 & $9 / 3$ и 6 & $3 / 3$ \\
\hline & Обратный праймер & 59,5 & $4 / 3$ & $1 / 3$ \\
\hline & Зонд & 64,5 & $12 / 3$ и 4 & $4 / 3$ \\
\hline \multirow{3}{*}{ DWV } & Прямой праймер & 60,2 & $5 / 3$ и 4 & $2 / 3$ \\
\hline & Обратный праймер & 60,1 & $4 / 3$ и 4 & $1 / 3$ \\
\hline & Зонд & 66,5 & $4 / 4$ & 0 \\
\hline
\end{tabular}

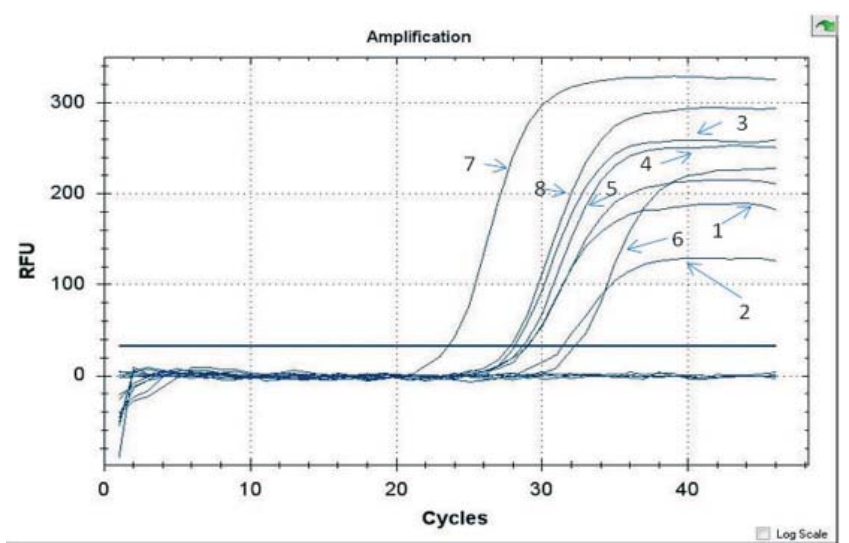

Амплификация маркерных локусов вирусов пчел на ДНК-матрице плазмидного положительного контроля:

1,5 - вирус мешотиатого расплода; 2,6 - вирус острого паралича; 3,7 - вирус черного маточника; 4,8 вирус деформации крыла; в концентрациях ДНК 100 пкг/мкл (1-4) и 10 пкг/мкл (5-8)

занных вирусов, при этом перекрестных реакций возможной амплификации не выявлено, что указывает на его высокую специфичность.

Сконструированный универсальный положительный контроль позволяет оценивать условия реакции при амплификации любого из исследуемых вирусов, что делает его пригодным в мультипраймерной ПЦР.

\section{СПИСОК ЛИТЕРАТУРЫ}

1. Биоинформационный анализ олигонуклеотидов для молекулярно-генетической индикации возбудителей аспергиллеза и аскосфероза пчел / Э.В. Ндайишимийе [и др.] // Ветеринарный врач. - 2015. - № 2. - С. 3-9.

2. Генетическая дифференциация популяций медоносных пчел (Apis mellifera L.) и распространение PHКсодержащих вирусов на фоне эпизоотии клеща Varroa destructor на территории Удмуртии / A.Е. Калашников [и др.] // Сельскохозяйственная биология. - 2013. № 4. - С. 88-92.

3. Горбунов А.В., Нефедова Н.С. Варрооз медоносной пчелы (Apis mellifera) в Саратовской области // Вестник Саратовского госагроуниверситета им. Н.И. Вавилова. - 2012. - № 7. - С. 18-19.

4. Калашников А.Е., Удина И.Г. Распространение РНК-содержащих пчел у медоносной пчелы (Apis mellifera) в отдельных регионах России // Молекулярная генетика, микробиология и вирусология. - 2017. T. 35. - № 1. - С. 31-35.

5. Клиническая и лабораторная диагностика заразных болезней расплода пчел / М.И. Гулюкин [и др.] // Ветеринария. - 2016. - № 4. - С. 25-27.

6. Оценка перспектив развития пчеловодства в Южной провинции Замбии /М.Н. Мукминов [и др.] // Ветеринария. - 2015. - № 10. - С. 49-52.

7. Оценка территории провинции Коппербелт Республики Замбия по уровню полиметаллического загрязнения для ведения пчеловодства / Э.В. Ндайишимийе [и др.] // Российский журнал. Проблемы ветеринарной санитарии, гигиены и экологии. - 2015. № 3(15). - С. 80-84.

8. Основные научные направления и итоги деятельности лаборатории ветеринарной санитарии в пчеловодстве /А.M. Смирнов [и др.] // Российский журнал. Проблемы ветеринарной санитарии, гигиены и экологии. - 2015. - № 1(13). - С. 26-31.

9. Поражение медоносной пчелы вирусами и паразитами и состояние пчелиных семей в разных эколого-географических условиях Большого Кавказа / Е.М. Ханбекова [и др.] // Сельскохозяйственная биология. - 2013. - № 6. - С. 43-54.

10. Угрозы распространения вирусных инфекций у пчел (Apis mellifera L.) и роль клеща Varroa destructor в развитии патологий / А.В. Спрыгин [и др.] // Сельскохозяйственная билогия. - 2016. - Т. 51. № 2. - C. 156-171.

11. Bernardi S., Venturino E. Viral epidemiology of the adult Apis mellifera infested by the Varroa destructor mite // Heliyon, 2016, Vol. 2(5), 43 pp.

12. Bilalov F., Skrebneva L., Nikitin O., Shuralev E.A., Mukminov $M$. Seasonal variation in heavy-metal accumulation in honey bees as an indicator of environmental pollution // Research Journal of Pharmaceutical, Biological and Chemical Sciences, - 2015, Vol. 6(4), P. 215-221.

13. Fujiyuki T., Takeuchi H., Ono M., Ohka S., Sasaki T., Nomoto A., Kubo T. Novel insect picorna-like virus identified in the brains of aggressive worker honeybees // Journal of Virology, 2004, V. 78(3), P. 1093-1100.

14. Reddy K.E., Yoo M.S., Kim Y.H., Kim N.H., Ramya M., Jung H.N., Thao le T.B., Lee H.S., Kang S.W. Homology differences between complete Sacbrood virus genomes from infected Apis mellifera and Apis cerana honeybees in Korea // Virus Genes, 2016, Vol. 52(2), P. 281-289.

15. Tehel A., Brown M.J., Paxton R.J. Impact of managed honey bee viruses on wild bees // Current Opinion in Virology, 2016, Vol. 19, P. 16-22.

16. Tsevegmid K., Neumann P., Yaez O. The honey bee pathosphere of Mongolia: European viruses in Central Asia // PLOS One, 2016, Vol. 11(3).

Хаммадова Альфия Василевна, магистрант, Казанский (Приволжский) федеральный университет. Россия.

Мукминов Малик Нилович, $\partial-p$ биол. наук, доцент, проф. кафедры «Прикладная экология», Казанский (Приволжский) федеральный университет. Россия.

Шуралев Эдуард Аркадьевич, канд. вет. наук, доцент 
кафедры «Прикладная экология», Казанский (Приволжский) федеральный университет. Россия.

420008, г. Казань, ул. Кремлевская, д. 18.

Тел.: (843) 236-50-62; e-mail: ecology@kpfu.ru.

Хаммадов Наиль Ильдарович, канд. биол. наук, ведущий научный сотрудник лаборатории биохимии и молекулярно-генетического анализа, Федеральный центр токсикологической, радиационной и биологической безопасности. Россия.

Фаизов Тагир Хадиевич, $\partial-p$ вет. наук, зав. лаборато- рией биохимии и молекулярно-генетического анализа, Федеральный центр токсикологической, радиационной и биологической безопасности. Россия.

420075, г. Казань, ул. Научный городок-2.

Тел.: (843) 239-53-20; e-mail:vnivi@mail.ru.

Ключевые слова: Apis mellifera L.; мультипраймерная ПЦР; вирус мешотчатого расплода; вирус острого паралича; вирус черного маточника; вирус деформации крыла.

\title{
METAGENOMIC ANALYSIS FOR HONEY BEE VIRUSES INDICATION BY MULTIPRIMER PCR
}

Khammadova Alfiya Vasilevna, Magistrandt, Kazan Federal University. Russia.

Mukminov Malik Nilovich, Doctor of Biological Sciences, Professor of the chair "Applied Ecology", Kazan Federal University. Russia.

Shuralev Eduard Arkadevich, Candidate of Veterinary Sciences, Leading Researcher, Laboratory of biochemistry and molecular genetics, Federal Center for Toxicological, Radiation and Biological Safety. Russia.

Khammadov Nail Ildarovich, Candidate of Biological Sciences, Leading Re-searcher, Laboratory of biochemistry and molecular genetics, Federal Center for Toxicological, Radiation and Biological Safety. Russia.

Faizov Tagir Khadievich, Doctor of Veterinary Sciences, Federal Center for Toxicological, Radiation and Biological Safety. Russia.
Keywords: Apis mellifera L.; multiprimer PCR; Sacbrood virus; Acute bee paralysis virus; Black queen cell virus; Deformed wing virus.

The purpose of this work was the design of primers for indication and identification of the causative agents of bee viral diseases (sacbrood, acute bee paralysis, black queen cell, deformed wing) by multiprimer PCR. Using the bioinformatics techniques, the design of the oligonucleotide primers was performed, which had similar annealing temperatures $\left(60^{\circ} \mathrm{C}\right)$ that allows each of the viruses to be identified under the same PCR conditions. Most of the known strains and isolates of these viruses are amplified with designed complex of oligonucleotide primers. Nucleotide sequences of primers and universal positive control allow genetic identification each of the presented biopathogens under the same PCR conditions at multiprimer format.

удк 636.2.034

\section{ПОЛИМОРФИЗМ ГЕНА СТЕАРИЛ-КОА КОДЕСАТУРЗЫ (SCD1) ДЛЯ ЛОКУСОВ КОЛИЧЕСТВЕННЫХ ПРИЗНАКОВ МОЛОЧНОЙ ПРОДУКТИВНОСТИ}

\author{
ЮЛЬМЕТЬЕВА Юлиана Рустэмовна, ТатНИИСХ ФИЦ КазНЦ РАН \\ САФИНА Наталья Юрьевна, ТатНИИСХ ФИЦ КазНЦ РАН; Казанская государственная \\ академия ветеринарной медицины имени Баумана
}

ШАРАФУТДИНОВ Газимзян Салимович, Казанский государственный аграрный университет ШАКИРОВ Шамиль Касымович, ТатНИИСХ ФИЦ КазНЦ РАН

\begin{abstract}
Повышения эффективности племенной работы невозможно достичь традиционными методами оценки племенной иенности. Применение днк-технологий открывает новые возможности в определении наследственной информации о животном, что позволит провести оценку, не дожидаясь собственной продуктивности. Поэтому иель наших исследований - поиск ассоциативных связей полиморфизма гена SCD1 с молочной продуктивностъю. Установлена генетическая характеристика структуры популяции, при этом распределение по частоте встречаемости соответствовало 0,54 (C) и 0,46 (T), в разрезе полиморфизма генотипов распределение составило 218 гол. с генотипом СС (20,2 \%), 739 гол. с генотипом СТ (68,6 \%) и 121 гол. с генотипом TT (11,2\%). Показано, ито коровы с генотипом SCD ${ }^{\text {тт }}$ иеют достоверное превосходство по надоенному молоку в динамике первых трех лактаций, а также по содержанию белка в молоке. Однако выход молочного жира был выше у животных с генотипом SCD1 ${ }^{c c}$.
\end{abstract}

Введение. Совершенствование селекционноплеменной работы в молочном скотоводстве осуществляется системой мероприятий, в которой большое значение имеет точность определения племенной ценности всего поголовья стада. Повышения точности оценки можно достичь, применяя методы ДНК-анализа, посредством которого определяется наследственная информация о животном [4].
Преимущество ДНК-технологий заключается в том, что можно определить генотип животного независимо от пола, возраста и физиологического состояния, что значительно повышает интенсивность селекции и снижает генерационный интервал между поколениями $[1,3]$.

Ген SCD1 кодирует ключевой фермент синтеза жирных кислот стерол-СоА десатуразу (дельта-9-десатуразу). Установлено, что однонуклеотидный по- 